\title{
PROBLEMATIKA PENERAPAN SISTEM KARANTINA WILAYAH DAN PSBB DALAM PENANGGULANGAN COVID-19
}

\author{
Putu Lantika Oka Permadhi, Fakultas Hukum Univesitas Mahasaraswati, \\ Email: LantikaOPE@unmas.ac.id \\ I Made Sudirga, Fakultas Hukum Univesitas Mahasaraswati, Email: \\ madesudirga084@gmail.com
}

doi: https://doi.org/10.24843/KS.2020.v08.i09.p06

\begin{abstract}
Abstrak
Wabah Covid-19 saat ini sudah menjadi masalah yang sangat serius hampir diseluruh negara di dunia. Pemerintah Indonesia juga sudah menetapkan kondisi kedaruratan kesehatan masyarakat terkait pandemi covid-19 dengan mengeluarkan 3 regulasi. Dikeluarkannya regulasi ini sebagai suatu bentuk perlindungan kesehatan untuk masyarakat dari segala penyakit dan/atau dari faktor resiko kesehatan masyarakat yang mempunyai potensi untuk menimbulkan suatu keadaan darurat kesehatan masyarakat dan juga untuk menstabilkan ekonomi negara ditengah pandemi covid-19. penelitian ini membahas mengenai problematika yang ada antara penerapan sistem karantina wilayah dan PSBB dalam penanggulangan covid19. Tujuan dari penelitian ini adalah untuk memahami apa itu Sistem Karantina Wilayah dan Sistem PSBB dalam masa Pandemi Covid-19 serta apa problematika yang terjadi dengan penerapannya ini sehingga masyarakat dapat mengetahui mengapa pemerintah menerapkan sistem ini untuk penanggulangan penyebaran virus Covid-19. Dalam pembahasan ditemukan adanya beberapa kendala-kendala yang terjadi dengan penerapan sistem karantina wilayah maupun PSBB. Dengan adanya berbagai problematika tersebut, diharapkan dalam hal ini pemerintah harus cermat dalam menentukan sistem kedaruratan mana yang harus digunakan dalam memutus pandemi covid-19 ini.
\end{abstract}

Kata Kunci : Covid-19, Karantina Wilayah, PSBB

\begin{abstract}
The Covid-19 outbreak has now become a very serious problem in all countries of the world. The Indonesian government has also determined the state of public health emergencies related to the covid-19 pandemic by issuing 3 regulations. The issuance of this regulation as a form of public health protection from all diseases and / or from public health risk factors that have the potential to cause a public health emergency and also to stabilize the country's economy amid the covid-19 pandemic. This study discusses the problems that exist between the application of the regional quarantine system and the PSBB in coping with covid-19. The purpose of this research is to understand what the Regional Quarantine System and PSBB System were during the Covid-19 Pandemic and what problems occurred with their implementation so that the public can find out why the government implemented this system to combat the spread of the Covid-19 virus. In the discussion, it was found that there were several obstacles that occurred with the implementation of the regional quarantine system and PSBB. With these various problems, it is hoped that in this case the government must be careful in determining which emergency system should be used in deciding this covid-19 pandemic.
\end{abstract}

Keywords: Covid-19, Regional Quarantine, PSBB 


\section{Pendahuluan}

\subsection{Latar Belakang Masalah}

Virus Corona atau yang biasa disebut dengan Covid-19 dewasa ini merupakan wabah penyakit yang sangat berbahaya yang menjangkiti hampir seluruh dunia. Suatu penyakit apabila merupakan penyakit menular yang berjangkit dengan cepat di daerah yang luas dan menimbulkan banyak korban disebut sebagai Epidemi. ${ }^{1}$ Dengan kata lain epidemi merupakan penyakit yang tidak secara tetap berjangkit di suatu daerah dan kadang disebut wabah. ${ }^{2}$ Epidemik suatu penyakit dapat mempengaruhi sejumlah besar individu di beberapa kawasan. Proporsi penduduk yang diserang disebut "ambang epidemik" dan jika kasusnya melampaui ambang epidemik maka disebut telah terjadi suatu "epidemik". Apabila seluruh dunia ikut mengalaminya maka disebut "pandemik". Dengan demikian Covid-19 ditetapkan sebagai Pandemi.

Covid-19 merupakan salah satu bagian dari keluarga virus yang menyebabkan penyakit pada hewan ataupun juga pada manusia. Di Indonesia, masih melawan Virus Corona hingga saat ini, begitupun juga di negara-negara lain. Jumlah kasus Virus Corona terus bertambah tiap harinya dengan beberapa melaporkan kesembuhan, tapi tidak juga sedikit yang meninggal. Usaha dalam penanganan dan pencegahan terus dilakukan demi melawan pandemi Covid-19. Virus Corona menyebabkan penyakit flu biasa sampai penyakit yang lebih parah seperti Sindrom Pernafasan Timur Tengah (MERS-CoV) dan Sindrom Pernafasan Akut Parah (SARS-CoV). Virus ini menular dengan cepat dan telah menyebar ke beberapa negara, termasuk Indonesia. Seseorang dapat tertular COVID-19 melalui berbagai cara, yaitu tidak sengaja menghirup percikan ludah dari bersin atau batuk penderita COVID-19, memegang mulut atau hidung tanpa mencuci tangan terlebih dulu setelah menyentuh benda yang terkena cipratan air liur penderita COVID-19 dan Kontak jarak dekat dengan penderita COVID-19, misalnya bersentuhan atau berjabat. ${ }^{3}$

kasusnya dimulai dengan pneumonia atau radang paru-paru misterius sekitar bulan Desember tahun 2019. Kasus infeksi pneumonia misterius ini mulai banyak ditemukan di pasar hewan yang berada di kota Wuhan tersebut. Virus Corona atau COVID-19 awalnya diduga dibawa oleh kelelawar dan hewan lain yang dimakan manusia hingga akhirnya terjadi penularan. Corona virus sebetulnya tidak asing dalam dunia kesehatan hewan, tapi hanya beberapa jenis yang mampu menginfeksi manusia hingga menjadi penyakit radang paru. Kasus ini diduga berkaitan dengan pasar hewan Huanan di Wuhan yang menjual berbagai jenis daging binatang, termasuk yang tidak biasa dikonsumsi seperti ular, kelelawar, dan berbagai jenis tikus. Dengan latar belakang tersebut, Virus Corona bukan kali ini saja memuat warga dunia panik. Memiliki gejala yang sama-sama mirip Flu, Virus Corona berkembang cepat hingga mengakibatkan infeks yang lebih parah dan gagal organ. Akibat dari maraknya virus corona ini mengakibatkan berbagai hal yang baru hampir dikerjakan dari rumah, baik sekolah, kuliah, bekerja ataupun aktivitas yang lainnya. Bahkan tempat beribadah pun sebagian telah ditutup demi mengurangi penyebaran virus corona ini. Dengan semakin meluasnya penyebaran Covid-19 yang semakin hari terus menular secara

1 Sri Kardjati, dkk., 1985, Aspek Kesehatan Dan Gizi Anak Balita, Yayasan Obor Indonesia, Jakarta, hal. 43.

2 Kamus Besar Bahasa Indonesia, 1995, Balai Pustaka, Jakarta, hal. 267.

3 Silpa Hanoatubun, 2020, Dampak Covid-19 Terhadap Perekonomian Indonesia, EduPsyCouns: Journal of Education, Psychology and Counseling Vol. 2 No. 1, Engkerang, hal. 146-153. 
meluas dan seakan tidak bisa tertangani serta kurangnya informasi membuat masyarakat di berbagai daerah banyak yang mengeluh, bingung dan semakin khawatir akibat tidak mendapatkan pelayanan secara aman dan meyakinkan ketika merasa ada indikasi terpapar virus Covid-19 dan munculnya masalah lain terkait permintaan dari sejumlah masyarakat untuk penetapan kebijakan lockdown, perlu adanya tindakan pemerintah pusat maupun daerah untuk menanggulanginya. ${ }^{4}$

Melihat keadaan yang demikian, dalam menanggulangi lebih jauh penyebaran Covid-19 ini, pemerintah Indonesia langsung mengeluarkan 3 (tiga) regulasi untuk melawan Covid-19. Ketiga regulasi tersebut yaitu:

1) Peraturan Pemerintah Pengganti Undang-Undang (Perppu) Nomor 1 Tahun 2020 tentang Kebijakan Keuangan dan Stabilitas Sistem Keuangan untuk Penanganan Pandemi Covid-19 dan/atau dalam rangka menghadapi ancaman yang membahayakan perekonomian Nasional dan/atau Stabilitas Sistem Keuangan (selanjutnya disebut Perppu No. 1/2020).

2) Peraturan Pemerintah Nomor 21 Tahun 2020 tentang Pembatasan Sosial Berskala Besar dalam rangka mempercepat penanganan Covid-19 (selanjutnya disebut PP No. 21/2020).

3) Keputusan Presiden Nomor 11 Tahun 2020 tentang Penetapan Kedaruratan Kesehatan Masyarakat Covid-10 (selanjutnya disebut Kepres No. 11/2020).

Dasar dikeluarkannya 3 regulasi tersebut adalah dari Undang-Undang Nomor 6 Tahun 2018 tentang Kekarantinaan Kesehatan (selanjutnya disebut UU No. 6/2018).

Penyelenggaraan kekarantinaan kesehatan di sini adalah tanggungjawab bersama antara Pemerintah Pusat dan Pemerintah Daerah sebagai suatu bentuk perlindungan kesehatan untuk masyarakat dari segala penyakit dan/atau dari faktor resiko kesehatan masyarakat yang mempunyai potensi untuk menimbulkan suatu keadaan darurat kesehatan masyarakat. Penyelenggaraan kekarantinaan wilayah ini dilakukan dengan cara kegiatan pengamatan penyakit dan faktor resiko kesehatan masyarakat terhadap alat angkut, orang, barang, dan/atau lingkungan, serta dari ketanggapan terhadap suatu kedaruratan kesehatan di masyarakat dalam bentuk karantina kesehatan. Salah satu tindakan kekarantinaan kesehatan adalah karantina wilayah dan juga Pembatasan Sosial Berskala Besar (PSBB). Tindakan-tindakan tersebut meliputi pembatasan dari kegiatan tertentu penduduk dalam suatu wilayah yang diduga sudah terinfeksi Covid-19, termasuk didalamnya yaitu pembatasan terhadap pergerakan orang dan/atau barang untuk satu provinsi atau kabupaten/kota tertentu dalam upaya memutus penyebaran Covid-19 ini. Pembatasan tersebut paling tidak dilakukan melalui meliburkan sekolah dan tempat kerja, membatasi sementara kegiatan keagamaan dan/atau juga pembatasan kegiatan di fasilitas-fasilitas umum. Meliburkan sekolah dan tempat kerja serta membatasi kegiatan keagamaan harus juga tetap mempertimbangkan kebutuhan pendidikan, produktivitas kerja, dan ibadah dari penduduk. Dalam pembatasan kegiatan pada umum atau fasilitas umum dilakukan dengan memperhatikan pemenuhan kebutuhan dasar penduduk. Yang dimaksud dengan "kebutuhan dasar penduduk", antara lain, kebutuhan pelayanan kesehatan, kebutuhan pangan, dan kebutuhan kehidupan sehari-hari lainnya.

Walaupun regulasi-regulasi tersebut didasarkan dari status kedaruratan kesehatan masyarakat akibat Covid-19 ini. Salah satu kebijakannya yaitu PSBB ini kemudian tetap menuai pro dan kontra dari beberapa kalangan. Di satu sisi banyak

${ }^{4}$ Dalinama Telaumbanua, 2020, Urgensi Pembentukan Aturan Terkait Pencegahan Covid-19 di Indonesia, Jurnal Pendidikan, Sosial, dan Agama Vol. 12 No. 1, Nias Selatan, hal, 59-70. 
kalangan yang menyatakan sikap untuk mendorong penerapan PSBB dimana hal tersebut dapat memutus mata rantai penularan dari Covid-19 ini dan juga tetap menjaga daya beli dari masyarakat. Namun di sisi lain, tidak sedikit pula kalangankalangan yang menyatakan sikap supaya pemerintah lebih mendorong untuk mengeluarkan regulasi tentang karantina wilayah yang dianggap bisa lebih efektif dalam menangani Covid-19 ini.

\subsection{Rumusan Masalah}

Dengan melihat latar belakang tersebut diatas, rumusan masalah yang dapat yaitu bagaimana mengenai problematika penerapan sistem karantina wilayah dan sistem PSBB dalam menanggulangi penyebaran Covid-19?

\subsection{Tujuan Penelitian}

\subsubsection{Tujuan Umum}

Dengan melihat latar belakang masalah diatas, tujuan umum dari penelitian ini adalah untuk memahami Sistem Karantina Wilayah dan Sistem PSBB dalam masa Pandemi Covid-19 serta problematika yang terjadi dengan penerapannya ini sehingga masyarakat dapat mengetahui mengapa pemerintah menerapkan sistem ini untuk penanggulangan penyebaran virus Covid-19.

1.3.2. Tujuan Khusus

Sesuai dengan permasalahan yang dikaji, maka tujuan khusus dari penelitian ini, adalah:

1). Untuk mengetahui dan menganalisis pengertian dari Sistem Karantina Wilayah dan Sistem PSBB sebagai bentuk penanggulangan penyebaran virus covid-19.

2). Untuk menganalisis apa yang menjadi problematika pada penerapan sistem karantina wilayah dan sistem PSBB dalam menanggulangi penyebaran covid 19

\section{Metode Penelitian}

Metode penelitian yang digunakan adalah metode penelitian hukum yuridis normatif, yang dimana penelitian ini lebih difokuskan untuk mengkaji penerapan dari kaidah-kaidah dan/atau norma-norma dalam hukum positif. ${ }^{5}$ Dalam penelitian ini, terdapat problematika yuridis dalam hal kekaburan norma di dalam penetapan UU No 6/2018 tentang Pembatasan Sosial Berskala Besar dalam rangka mempercepat penanganan Covid-19. Sedangkan pendekatan yang digunakan adalah konsepsi legis positivis yang dimana dalam konsepsi ini memandang hukum merupakan suatu sistem normatif yang bersifat mandiri, tertutup dan terlepas dari kehidupan masyarakat yang nyata. ${ }^{6}$

Sumber hukum dalam penelitian hukum normatif ada tiga yaitu bahan hukum primer, bahan hukum sekunder dan bahan hukum tersier. Bahan hukum dalam penelitian ini diperoleh dari UU No 6/2018 dan PP No 21/2020. Analisis data dilakukan untuk memecahkan masalah yang tertuang dalam rumusan masalah dengan menggunakan analisis data deskriptif kualitatif yaitu menggambarkan

${ }^{5}$ Johnny Ibrahim, 2006, Teori dan Metodologi Penelitian Hukum Normatif, Bayumedia Publishing, Malang, hal. 295.

6 Ronny Hanitijo Soemitro, 1988, Metodologi Penelitian Hukum dan Jurimetri, Ghalia Indonesia, Jakarta, hal. 13-14. 
problematika yang timbul akibat diberlakukannya PP No. 21 Tahun 2020 tentang PSBB.

\section{Hasil dan Pembahasan}

\subsection{Pengertian Karantina Wilayah dan PSBB}

Perlu dipahami sebelumnya, bahwa yang dimaksud kekarantinaan kesehatan dalam latar belakang diatas adalah suatu upaya mencegah dan menangkal keluar atau masuknya penyakit dan/atau faktor resiko kesehatan masyarakat yang berpotensi menimbulkan kedaruratan kesehatan masyarakat sesuai dalam Pasal 1 Angkat 1 UU No. 6/2018. Kedaruratan kesehatan masyarakat di sini merupakan kejadian kesehatan masyarakat yang bersifat luar biasa dengan ditandai penyebaran penyakit menular dan/atau kejadian yang disebabkan oleh radiasi nuklir, pencemaran biologi, kontaminasi kimia, bioterorisme dan pangan yang menimbulkan bahaya kesehatan dan berpotensi menyebar lintas wilayah atau lintas negara sesuai dalam Pasal 1 Angka 2 UU No. 6/2018. Lebih lanjut, dalam UU No. 6/2018 juga mengamanatkan bahwa pemerintah pusat dan pemerintah daerah bertanggung jawab melindungi kesehatan masyarakat dari penyakit dan/atau faktor risiko kesehatan masyarakat yang berpotensi menimbulkan kedaruratan kesehatan melalui penyelenggaraan kekarantinaan masyarakat.

Dalam UU No. 6/2018, terdapat beberapa model Karantina. Dimana syarat utama dalam melakukan karantina adalah penentuan status darurat kesehatan nasional oleh Pemerintah Pusat, yang dalam hal ini adalah Presiden, dan diikuti dengan pembentukan satuan tugas (satgas) untuk melakukan tindakan yang diperlukan dalam menangani sebuah wabah penyakit. Model karantina wilayah ada 3 jenis, yaitu Karantina Rumah, Karantina Wilayah dan Karantina Rumah Sakit.

Pasal 1 Angka 8 UU No. 6/2018 menyebutkan bahwa karantina rumah adalah pembatasan penghuni dalam suatu rumah beserta isinya yang diduga terinfeksi penyakit dan/atau terkontamisasi sedemikian rupa untuk mencegah kemungkinan penyebaran penyakit atau terkontaminasi. Secara khusus, karantina rumah dijelaskan dalam pasal 50, 51 dan pasal 52. Karantina rumah ini dilakukan hanya kalau kedaruratannya terjadi di satu rumah. Karantina ini meliputi orang, rumah dan alat angkut yang dipakai. Orang yang dikarantina tidak boleh keluar, tapi kebutuhan mereka dijamin oleh negara.

Pasal 1 Angka 9 UU No. 6/2018 menyebutkan bahwa karantina Rumah Sakit adalah pembatasan seseorang dalam rumah sakit beserta isinya yang diduga terinfeksi penyakit dan/atau terkontamisasi sedemikian rupa untuk mencegah kemungkinan penyebaran penyakit atau terkontaminasi. Secara khusus, karantina rumah sakit dijelaskan pada pasal 56, 57 dan pasal 58. Karantina rumah sakit ini dilakukan apabila wabah bisa dibatasi hanya di dalam satu atau beberapa rumah sakit saja. Rumah Sakit tersebut diberi tanda garis batas dan dijaga aparat, dan mereka yang dikarantina dijamin kebutuhan dasarnya oleh pemerintah.

Pasal 1 Angka 10 UU No. 6/2018 menyebutkan bahwa karantina wilayah adalah pembatasan penduduk dalam suatu wilayah termasuk wilayah pintu masuk beserta isinya yang diduga terinfeksi penyakit dan/atau terkontaminasi sedemikian rupa untuk mencegah kemungkinan penyebaran penyakit atau terkontaminasi. Pembahasan karantina wilayah ini dijelaskan lebih khusus dalam pasal 53, 54 dan 55. Dimana syarat pelaksanaan diantaranya ketika ada penyebaran penyakit di antara masyarakat secara meluas. Dalam situasi seperti ini harus dilakukan penutupan wilayah untuk menangani wabah ini. Wilayah yang dikunci diberi tanda karantina, 
dijaga oleh aparat, anggota masyarakat tidak boleh keluar masuk wilayah yang dibatasi, dan kebutuhan dasar mereka wajib dipenuhi oleh pemerintah. Secara umum di negara lainnya, lebih dikenal istilah Lockdown. Kemudian, dalam Pasal 8 UU No. 6/2018 juga ditegaskan pelayanan kesehatan dasar didapatkan sesuai dengan kebutuhan medis, kebutuhan pangan dan kebutuhan kehidupan sehari-hari lainnya selama dilakukan karantina wilayah. Yang dimaksud dengan kebutuhan kehidupan sehari-hari lainnya yaitu diberikannya kebutuhan berupa pakaian dan perlengkapan mandi, cuci dan buang air (MCK). Selain hal tersebut, setiap orang yang terdampak karantina wilayah mempunyai hak untuk dapat memperoleh perlakuan yang sama dalam penyelenggaraan kekarantinaan kesehatan.

Di sisi lain, juga terdapat tindakan penyebaran selain karantina wilayah yaitu dengan diberlakukannya Pembatasan Sosial Berskala Besar (PSBB) sebagaimana sudah dijelaskan diatas. Dalam UU No. 6/2018 Pasal 1 Angka 11 menyebutkan PSBB adalah pembatasan kegiatan tertentu penduduk dalam suatu wilayah yang diduga terinfeksi penyakit dan/atau terkontaminasi sedemikian rupa untuk mencegah kemungkinan penyebaran penyakit atau kontaminasi. Secara khusus dalam Pasal 1 PP No. 21/2020, Pembatasan Sosial Berskala Besar ini berarti pembatasan kegiatan tertentu penduduk dalam suatu wilayah yang diduga terinfeksi Covid-19 sedemikian rupa untuk mencegah kemungkinan penyebaran virus tersebut. PSBB ini mempunyai tujuan untuk mencegah meluasnya penyebaran penyakit kedaruratan kesehatan masyarakat yang sedang terjadi antar orang di suatu wilayah tertentu. Perlu diingat bahwa, baik penetapan karantina suatu wilayah maupun pembatasan sosial berskala besar ditetapkan oleh Menteri Kesehatan. Dengan disetujui oleh Menteri Kesehatan, pemerintah dalam hal ini yaitu pemerintah daerah dapat pula melakukan pembatasan sosial berskala besar atau pembatasan terhadap pergerakan orang dan barang untuk satu provinsi atau kabupaten/kota tertentu saja.

\subsection{Problematika Penerapan Karantina Wilayah dan PSBB}

Seperti yang sudah diketahui, dalam hukum pada dasarnya adalah dari kemauan publik, jadi tidak hanya sekedar hukum dalam pengertian saja. Sociological Jurisprudence juga menunjukkan adanya kesepakatan yang cermat antara hukum yang tertulis sebagai kebutuhan dari masyarakat hukum untuk terciptanya kepastian hukum (positivism law) dan living law sebagai wujud penghargaan terhadap pentingnya peranan masyarakat dalam pembentukan hukum dan orientasi hukum. ${ }^{7}$

Roscoe Pound dengan teorinya yaitu Law as a tool of social engineering atau Hukum adalah alat untuk memperbaharui atau merekayasa masyarakat. dalam istilah ini hukum diharapkan dapat berperan merubah nilai-nilai sosial dalam masyarakat. Sedangkan menurut pendapat Mochtar Kusumaatmadja, konsepsi hukum sebagai sarana pembaharuan masyarakat Indonesia lebih luas jangkauan dan ruang lingkupnya, alasannya oleh karena lebih menonjolnya perundang-undangan dalam proses pembaharuan hukum di Indonesia (walau yurisprudensi memegang peranan pula) dan ditolaknya aplikasi mekanisme daripada konsepsi tersebut yang digambarkan akan mengakibatkan hasil yang sama daripada penerapan faham legisme yang banyak ditentang di Indonesia. ${ }^{8}$

7 Munir Fuadi, 2013, Teori-Teori Besar (Grand Theory) Dalam Hukum, Kencana Prennamdeia Group, Jakarta, hal 248.

8 Mochtar Kusumaatmadja, 2005, Hukum, Masyarakat, dan Pembangunan, Binacipta, Bandung, hal. 62-63. 
Harus disadari dan diwaspadai bahwa penyebaran dari Covid-19 ini dinyatakan oleh Organisasi Kesehatan Dunia (WHO) adalah sebagai pandemi pada sebagian besar negara-negara di seluruh dunia, termasuk didalamnya yaitu Indonesia. Covid-19 ini terus menunjukkan peningkatan dari waktu ke waktu serta telah menimbulkan bayak korban jiwa dan juga kerugian material yang sangat besar sehingga berimplikasi pada aspek lainnya sosial, politik dan kesejahteraan dari masyarakat.

Selain itu, implikasi dari dampak pandemi Covid-19 ini yaitu terjadinya perlambatan pertumbuhan ekonomi nasional, adanya penurunan dari penerimaan negara, serta terjadi peningkatan belanja negara dan dari segi pembiayaannya sehingga diperlukan berbagai upaya dari pemerintah baik itu pusat maupun daerah untuk berupaya lebih keras dalam melakukan tindakan penyelamatan kesehatan serta untuk penyelamatan perekonomian nasional dengan difokuskan pada upaya belanja untuk kesehatan, jaringan pengaman nasional serta pemulihan perekonomian termasuk untuk dunia usaha dan masyarakat yang terdampak oleh pandemi Covid-19 ini.

Oleh sebab itu, dengan dikeluarkannya peraturan-peraturan dalam rangka penanggulangan penyebaran Covid-19 sesuai dengan kebutuhan untuk menjaga warga negara yaitu salah satunya Perppu No. 1/2020 diharapkan mampu untuk mengantisipasi implikasi dari pandemi Covid-19 sehingga keadaan perekonomian yang sekarang ini memburuk dari sistem keuangan yang ditunjukkan dengan adanya penurunan berbagai aktivitas ekonomi domestik maupun internasional sehingga perlu dimitigasi bersama oleh Pemerintah dan Komite Stabilitas Sistem Keuangan (KSSK) untuk melakukan tindakan antisipasi dalam rangka menjaga stabilitas sektor keuangan. Mitigasi di sini disebut sebagai mitigasi bencana yang dimana adalah upaya untuk mengurangi risiko yang ditimbulkan oleh bencana apabila terjadi suatu bencana. ${ }^{9}$ Fokus dalam mitigasi bencana adalah untuk mengurangi dampak dari ancaman sehingga dampak negatif yang ditimbulkan akan berkurang. Terkait hal tersebut, perlu segera diambil suatu kebijakan dan langkah-langkah luar biasa dalam rangka penyelamatan perekonomian nasional dan stabilitas sistem keuangan melalui berbagai kebijakan relaksasi yang berkaitan dengan pelaksanaan APBN khususnya dengan melakukan peningkatan belanja untuk kesehatan, pengeluaran untuk jaring pengaman sosial dan pemulihan perekonomian, serta memperkuat kewenangan berbagai lembaga dalam sektor keuangan.

Dalam Undang-Undang No. 6/2018 tentang Kekarantinaan Kesehatan, pemerintah pusat diberikan beberapa opsi yaitu untuk menerapkan PSSB atau Karantina Wilayah. Adapun perbedaan antara Karantina Wilayah dan Pembatasan Sosial Berskala Besar dapat dilihat dalam Pasal 1 angka 10 dan 11 UU No 6 Tahun 2018 tentang Kekarantinaan Kesehatan. Karantina Wilayah adalah pembatasan penduduk dalam suatu wilayah termasuk wilayah Pintu Masuk beserta isinya yang diduga terinfeksi penyakit dan/atau terkontaminasi sedemikian rupa untuk mencegah kemungkinan penyebaran penyakit atau kontaminasi. Sedangkan PSBB adalah pembatasan kegiatan tertentu penduduk dalam suatu wilayah yang diduga terinfeksi penyakit dan/atau terkontaminasi sedemikian rupa untuk mencegah kemungkinan penyebaran penyakit atau kontaminasi. Inti dari 2 (dua) opsi tersebut yaitu Karantina

9 Nurjanah, R. Sugiharto, Kuswanda Dede, Siswanto BP, Adikoesoemo, 2013, Manajemen Bencan, Alfabeta, Bandung, hal. 54. 
Wilayah bertujuan untuk dilakukan pembatasan penduduk dalam satu wilayah, sedangkan PSBB adalah upaya untuk pembatasan kegiatan tertentu penduduk.

Dalam implementasinya, penerapan PSBB tidak mempunyai implikasi hukum dikarenakan tindakan ini hanya berbentuk sebuah himbauan kepada masyarakat dan diperkuat lagi dengan tidak adanya sanksi atau upaya hukum lebih lanjut dalam PP No. 21/2020, demikian pula opsi PSBB ini juga tidak terlalu mengganggu aspek ekonomi dan daya beli masyarakat secara umum. Kegiatan tersebut hanya membatasi aspek-aspek secara umum saja seperti dengan cara meliburkan sekolah, membatasi waktu tempat kerja dengan menggunakan metode Work From Home (WFH), membatasi kegiatan-kegiatan agama dan/atau membatasi kegiatan masyarakat ditempat atau fasilitas umum. Yang artinya, tindakan PSBB ini masih tetap mengakomodasikan pergerakan masyarakat, namun masyarakat masih tetap dapat melaksanakan kegiatan sehari-hari, hanya kegiatan-kegiatan tertentu yang dbatasi.

Walaupun disatu sisi, PSBB masih memberikan cukup ruang bagi masyarakat untuk beraktivitas dan untuk memenuhi kebutuhan hidupnya, disisi lain PSBB juga hanya dalam bentuk himbauan saja yang dimana dianggap tidak memiliki upaya paksa untuk pergerakan masyarakat khususnya dalam hal pencegahan penyebaran Covid-19. Hal ini terbukti yang dimana awalnya pemerintah memberi himbauan dengan melakukan social distancing beberapa waktu lalu, tapi penyebaran Covid-19 ini tetap masih terus meningkat dari hari ke hari. Oleh sebab itu, tidak salah dikemudian hari banyak pihak menganggap bahwa PSBB tidak akan efektif dalam menangani pandemi ini.

Di satu sisi memang PSBB masih memberikan ruang bagi masyarakat untuk beraktivitas dan memenuhi kebutuhan hidupnya, namun disisi lain PSBB yang hanya berbentuk imbauan ini dianggap tidak memiliki upaya paksa bagi pergerakan masyarakat khususnya dalam pencegahan penyebaran Covid-19, terbukti dengan telah dilakukannya social distancing dalam beberapa waktu ini namun tetap saja penyebaran virus corona terus meningkat. Sehingga tidak salah kemudian banyak pihak beranggapan bahwa PSBB tidak efektif dalam menangai Covid-19.

Berbeda halnya dengan Karantina Wilayah, dimana tindakan ini secara implementasinya di masyarakat tentu memiliki daya paksa yang lebih kuat. Hal ini bisa dilihat, apabila suatu wilayah dikarantina, aturan-aturan yang diberlakukan sangat jelas seperti wilayah tersebut akan diberikan semacam garis karantina dan dijaga terus menerus oleh pejabat yang berwenang. Pada saat karantina tersebut berlaku, warga masyarakat tidak boleh lagi untuk keluar masuk wilayah tersebut.

Sisi baiknya, sesuai dengan Pasal 55 UU No. 6/2018, kebutuhan hidup pokok masyarakat dan makanan hewan ternak yang berada pada wilayah karantina tersebut menjadi tanggung jawab dari pemerintah pusat dan juga dalam pelaksanaannya melibatkan pemerintah daerah dan pihak yang terkait. Sedangkan PSBB, walaupun pemerintah memberikan bantuan berupa bahan pokok, uang maupun lainnya terhadap sebagian masyarakat, tidak ada jaminan dari negara untuk menanggung kebutuhan hidup masyarakat. Hal tersebut akhirnya akan menimbulkan dugaan dari beberapa kalangan apabila opsi yang diambil oleh pemerintah yaitu PSBB ini lantaran khawatir dengan masalah ekonomi yang akan timbul dikemudian hari. Sebab, dengan pemerintah mengambil tindakan berupa karantina wilayah menjadikan pemerintah harus menanggung kebutuhan hidup masyarakat di wilayah yang dikarantina

Dengan begitu, apabila opsi yang dipilih dikemudian hari adalah PSBB akan menjadi problematika yang sangat pelik, dalam problematika yuridis yang sudah diketahui bersama, UU No 6/2018 mensyaratkan bahwa sebelum presiden 
menetapkan darurat kesehatan, perlu terlebih dahulu menetapkan syarat dan tata cara penetapan dan pencabutan keadaan darurat kesehatan melalui Peraturan Pemerintah. Setelah itu, barulah dirumuskan kriteria dan metode pelaksanaan karantina rumah, karantina wilayah, karantina rumah sakit, dan PSBB sebagai salah satu tindakan dalam keadaan darurat. Hak warga negara dan kewajiban negara selama tindakan darurat itu berlangsung yang seharusnya juga diatur dengan Peraturan Pemerintah yang sama. Artinya UU No 6/2018 menghendaki adanya keselarasan tindakan dalam keadaan darurat kesehatan tersebut. Tapi, tidak demikian dengan PP No 21/2020 yang dimana tidak mengatur mengenai syarat dan tata cara penetapan dan pencabutan keadaan darurat kesehatan dan tidak ada tolak ukur yang jelas kapan presiden harus menetapkan dan mencabut keadaan darurat kesehatan nasional.

Akibatnya, hingga sekarang kriteria itu masih didasarkan pada subjektifitas presiden. selanjutnya, PP No 21/2020 ini juga sifatnya parsial karena hanya mengatur tentang tindakan PSBB dalam keadaan darurat. Seharusnya dalam PP No 21/2020 yang sama juga diatur tentang kriteria dan metode pelaksanaan karantina rumah, karantina rumah sakit, dan karantina wilayah yang juga merupakan tindakan pemerintah dalam keadaan darurat sesuai mandat UU No 6/2018. PP No 21/2020 ini juga dibentuk hanya untuk penanganan COVID-19. Padahal, Peraturan Pemerintah adalah aturan hukum yang berlaku umum atau tidak berlaku hanya mengacu pada satu peristiwa saja sehingga harus mengatur untuk semua kasus, baik yang sedang atau yang akan terjadi di masa depan. Jika tidak demikian, maka setiap ada kejadian baru, kita akan membuat aturan lagi. Selain tidak efisien, ini bertolak belakang dengan niat Presiden untuk menyederhanakan regulasi.Selain itu, PP No 21/2020 ini juga tidak mengatur hak warga negara dan kewajiban negara selama tindakan darurat berlangsung sehingga kecukupan kebutuhan dasar warga negara selama keadaan darurat tidak mendapat jaminan hukum. sedangkan dalam hal problematika ekonomi, apabila ditengah perkembangan ekonomi negara kita saat ini yang belum stabil, ditambah dengan masih banyaknya utang negara, apakah Indonesia akan mampu untuk menanggung berbagai dampak terkait ekonomi apabila nantinya diambil kebijakan karantina wilayah. Jangan sampai sebuah kebijakan diambil namun justru berujung pada ambruknya perekonomian negara dan korban jiwa akibat chaos secara ekonomi. Oleh sebab itu, perlu dibuat kebijakan dengan berlandaskan konsep economic approach to the laws atau pendekatan ekonomi terhadap hukum yang mana kebijakan yang dikeluarkan tidak semata-mata membedah untuk menemukan limitasi hukum melalui dimensi hukum dan ekonomi dengan cara pertimbangan ekonomis yang bukan menjadi alasan menghilangkan atau menyampaikan namun dilihat dari pertimbangan efisiensi, nilai, efektif dan lainnya sebagaimana yang merupakan konsep-konsep fundamental hukum ekonomi serta dapat mempertemukan kedua kutub hukum yaitu keadilan dan kepastian hukum. ${ }^{10}$

Beberapa negara berhasil menekan angka laju penularan dan juga angka kematian dari Covid-19 ini. Namun, beberapa negara lainnya justru sedang mengalami masa kritis dengan jumlah kasus konfirmasi dan kematian akibat Covid-19 ini meningkat. Kondisi demikian tentu dapat menjadi pertimbangan bagi pemerintah, sebut saja Italia yang lalai dan tidak mengantipasi dengan cepat penularan dan penanganan virus ini, ataupun India yang menerapkan kebijakan Lockdown tanpa perencanaan yang matang. Berbagai dilematis dan problematis penanganan Covid-19

10 Fajar Sugianto, 2013, Economic Approach to Law, Analisis Keekonomian Tentang Hukum, Kencana Prenada Media Grup, Jakarta, hal. 112. 
ini tentunya membutuhkan kerjasama seluruh kalangan. Tidak salah bila kita mengkritik kebijakan pemerintah, namun melemparkan semua kesalahan dan kegagalan penanganan Covid-19 hanya kepada pemerintah tentu bukanlah tindakan yang bijak. Bahu membahu, saling mengingatkan, turut patuh, mendukung dan saling mendorong upaya pencegahan penyebaran virus Corona menjadi point terpenting yang perlu dilakukan saat ini. Apapun kebijakan yang diambil pemerintah, selama rakyatnya tidak bisa dan tidak mau bekerja sama tentu solusi percepatan penanganan Covid-19 hanya akan terus menerus menjadi sebuah harapan.

\section{Kesimpulan}

Dalam problematika yuridis yang sudah diketahui bersama, UU No 6/2018 mensyaratkan bahwa sebelum presiden menetapkan darurat kesehatan, perlu terlebih dahulu menetapkan syarat dan tata cara penetapan dan pencabutan keadaan darurat kesehatan melalui PP. Setelah itu, barulah dirumuskan kriteria dan metode pelaksanaannya. Tapi, tidak demikian dengan PP No 21/2020 yang dimana tidak mengatur mengenai syarat dan tata cara penetapan dan pencabutan keadaan darurat kesehatan dan tidak ada tolak ukur yang jelas kapan presiden harus menetapkan dan mencabut keadaan darurat kesehatan nasional. Sedangkan dalam problematika ekonominya, apabila ditengah perkembangan ekonomi negara kita saat ini yang belum stabil, ditambah dengan masih banyaknya utang negara, apakah Indonesia akan mampu untuk menanggung berbagai dampak terkait ekonomi apabila nantinya diambil kebijakan karantina wilayah. Oleh sebab itu, apabila ditelaah lebih mendalam lagi dan melakukan perbandingan, meskipun angka case Covid-19 bertambah dan menimbulkan korban, namun secara matematis angka kematian karena Covid-19 dibanding jumlah penduduk Indonesia yang sehat/belum terjangkit Covid-19 masih jauh lebih kecil, artinya kondisi demikian menunjukkan masih adanya kesempatan bagi kita untuk menerapkan PSBB secara lebih serius agar jumlah penduduk terjangkit Covid-19 tidak bertambah. Sehingga dalam hal ini Pemerintah harus berkeyakinan bahwa PSBB merupakan opsi terbaik dari segi pencegahan (bukan penyembuhan) agar tidak terlalu mengganggu perekonomian Indonesia.

\section{Daftar Pustaka \\ Buku}

Fuadi, Munir, Teori-Teori Besar (Grand Theory) Dalam Hukum, Kencana Prennamdeia Group, Jakarta, (2013)

Ibrahim, Johnny, Teori dan Metodologi Penelitian Hukum Normatif, Bayumedia Publishing, Malang, (2006)

Kardjati, Sri, dkk., Aspek Kesehatan Dan Gizi Anak Balita, Yayasan Obor Indonesia, Jakarta, (1985)

Kamus Besar Bahasa Indonesia, Balai Pustaka, Jakarta, (1995)

Kusumaatmadja, Mochtar, Hukum, Masyarakat, dan Pembangunan, Binacipta, Bandung, (2005)

Nurjanah, R. Sugiharto, Kuswanda Dede, Siswanto BP, Adikoesoemo, Manajemen Bencana, Alfabeta, Bandung, (2013)

Sugianto, Fajar, Economic Approach to Law, Analisis Keekonomian Tentang Hukum, Kencana Prenada Media Grup, Jakarta, (2013)

Soemitro, Ronny Hanitijo, Metodologi Penelitian Hukum dan Jurimetri, Ghalia Indonesia, Jakarta, (1988) 


\section{Jurnal}

Telaumbanua, Dalinama. "Urgensi Pembentukan Aturan Terkait Pencegahan Covid-19 Di Indonesia." QALAMUNA: Jurnal Pendidikan, Sosial, dan Agama 12, no. 1 (2020): 59-70. https://doi.org/10.37680/qalamuna.v12i01.290

Hanoatubun, Silpa. "Dampak Covid-19 terhadap Prekonomian Indonesia." EduPsyCouns: Journal of Education, Psychology and Counseling 2, no. 1 (2020): 146-153.

\section{Peraturan Perundang-Undangan}

Peraturan Pemerintah Pengganti Undang-Undang (Perppu) Nomor 1 Tahun 2020 tentang Kebijakan Keuangan dan Stabilitas Sistem Keuangan untuk Penanganan Pademi Covid-19 dan/atau dalam rangka menghadapi ancaman yang membahayakan perekonomian Nasional dan/atau Stabilitas Sistem Keuangan.

Peraturan Pemerintah Nomor 21 Tahun 2020 tentang Pembatasan Sosial Berskala Besar dalam rangka mempercepat penanganan Covid-19.

Keputusan Presiden Nomor 11 Tahun 2020 tentang Penetapan Kedaruratan Kesehatan Masyarakat Covid-10. 